\title{
PENDIDIKAN KELUARGA PERSPEKTIF AL-QURAN DAN HADITS
}

\author{
M. Miftah Arief \\ IAI Darussalam Martapura \\ Email: miftaharief@iai-darussalam.co.id \\ Mihrab Afnanda \\ IAI Darussalam Martapura \\ Email: mihrabafnanda@iai-darussalam.ac.id
}

\begin{abstract}
Islamic education should provide young Muslims with the opportunity to learn about their religion. The meaning of education is to develop physical and spiritual potential to obtain certain values and norms. These educational activities can take place in a family, school, or community. The family, school and community are environments that can shape human character. While these three factors influence each other, parenting has the greatest impact on children's education. If the family manages to build a home, the roles of school and community will complement each other. The family is the first and most important environment for a child. This is because the child has a blood bond with his parents that cannot be separated for the rest of his life. Parental consent and parental consent have a large impact on children's behavior. So many moral ailments are caused by the atmosphere of family life. The family is everything to the child. In other words, the picture of the family can be seen from the child's character, habits and morals.
\end{abstract}

Keywords: Family Education, Perspective of the Qur'an and Hadith.

\section{A. Pendahuluan}

Ujung tombak perkembangan dunia pendidikan ditandai dengan berkembangnya ilmu pengetahuan, sedangkan ilmu pengetahuan dapat dianalogikan sebuah rumah yang mana rumah tersebut memiliki tongkat atau pondasi sedangkan pondasi ini dapat diartikan sebuah pendidikan, analogi ini memberi gambaran bahawa betapa pentinggnya sebuah pendidikan, hal ini sejalan dengan rumah yang tidak memiliki tongkat atau pondasi maka tentu tidak akan kokoh. Seperti yang terjadi pada bulan lalu tentang "seorang bocah perempuan berusia 6 tahun disiksa ibu kandung dan kekasih ibu kandungnya sendiri. Ia mengalami luka-luka dan patah tulang tangan. Tak hanya itu, sang ibu dan kekasihnya tega meninggalkan anak malang ini begitu saja disebuah pemukiman warga" ${ }^{103}$ Tentu bagi orang

103 Reza Zakaria, News liputan 6, 25 Agu 2020, 18:00 WIB, https:// www.liputan6.com/regional/read/4339396/video-bocah-6-tahun-babak-belur-dan- 
yang normal disaat kita mendengar berita seperti ini dipenuhi dengan rasa kasian dan iba terhadap yang terjadi, orangtua sebagai kelurga yang seharusnya tempat yang nyaman bagi anak tetapi yang terjadi malah sebaliknya. Dapat dipastikan hancurnya sikologi anak tersebut, serangan sikologi seperti inilah yang banyak menyebabkan hancurnya proses perkembangan anak dari sudut pendidikan.

Banyak orang tua yang tidak menyadari bahwa mereka adalah sekolah atau lembaga pendidikan pertama bagi anak-anaknya. Hal ini diperkuat dengan banyaknya fenomena orang tua yang menyerahkan penuh anaknya pada pengasuhan asisten rumah tangga atau pada lembaga pendidikan formal, padahal pengasuhan anak dalam lingkungan keluarga berdampak besar pada pendidikan dan perilaku anak dan merupakan pondasi utama dan boleh dikatakan pendidikan pertama bagi anak. Keluarga memiliki peran penting dalam pendidikan, baik dalam masyarakat Islam maupun nonIslam. Karena keluarga adalah tempat pertama tumbuh kembang anak. Dalam keluarga, ia mengambil sifat positif dan negatif dari anggotanya saat ia berkembang selama tahun-tahun pembentukannya (Usia pra sekolah).

Tujuan tulisan ini ingin mendeskripsikan dan pengetahuan dalam hal memahamkan kaidah serta konsep dalam pendidikan yang berorientasi pada pendidikan keluarga dalam perspektif Al-Qur'an dan Hadits. Metode penulisan ini menggunakan library research yang lebih menekankan pengumpulan-pengumpulan berbagai teori dan pandangan sehingga nantinya didapatkan kejelasan bagaiman pendidikan keluarga yang baik diimplimentasikan pada ranah kehidupan keluarga.

\section{B. Pembahasan}

Pendidikan dalam Undang-Undang Republik Indonesia Nomor 20 Tahun 2003 Tentang Sistem Pendidikan Nasional pada bagian Dasar, Fungsi, dan Tujuan pendidikan, pasal 3 yang berbunyi:

"Pendidikan nasional berfungsi mengembangkan kemampuan dan membentuk watak serta peradaban bangsa yang bermartabat dalam rangka mencerdaskan kehidupan bangsa, bertujuan untuk berkembangnya potensi peserta didik agar menjadi manusia yang beriman dan bertakwa kepada Tuhan Yang Maha Esa, berakhlak mulia, sehat, berilmu, cakap, kreatif, mandiri, dan menjadi warga negara yang demokratis serta bertanggung jawab". 104

patah-tulang-disiksa-ibu-kandung-dan-kekasihnya, diakses pada Rabu, 23 September 2020, Pukul15.22 Wita.

104 Undang-Undang Republik Indonesia Nomor 20 Tahun 2003 Tentang Sistem Pendidikan Nasional. 
Agama Islam memberi perhatian besar mengenai pendidikan, hal ini disebabkan pendidikan merupakan sentral utama dalam membentuk manusia menjadi makhluk mulia lebih tegasnya tertuang pada surah Q.S. atTin;

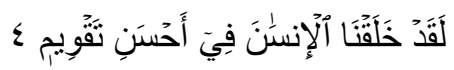

Artinya: "Sesungguhnya Kami telah menciptakan manusia dalam bentuk yang sebaik-baiknya". 105

Selain itu di dalam al-Qur'an Allah SWT memperkenalkan diri-Nya sebagai al-Murabbi (Maha Pendidik) dan al-Mu"allim (Maha Guru) tertuang pada surah al-Fatihah ayat 2 dan al-Baqarah ayat 31:

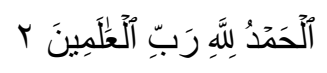

Artinya: "Segala puji bagi Allah, Tuhan semesta alam". ${ }^{106}$

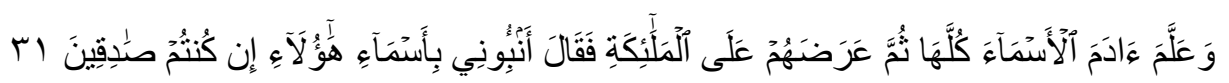

Artinya: "Dan Dia mengajarkan kepada Adam nama-nama (benda-benda) seluruhnya, kemudian mengemukakannya kepada para Malaikat lalu berfirman: "Sebutkanlah kepada-Ku nama benda-benda itu jika kamu mamang benar orang-orang yang benar". 107

Bila kita telaah dengan seksama dari terjemahan surah al-Fatihah ayat 2 dan surah al-Baqarah ayat 2 di atas maka saling berkaitan dan dapat ditarik simpulan bahwa segala puji bagi Allah, Rabb (Tuhan) semesta alam."Kata Rabb (Tuhan) berarti: Tuhan yang ditaati yang Memiliki, Mendidik dan Memelihara. Secara keseluruhan mulai dari keterangan UUD tentang fungsi, dan tujuan pendidikan dengan ayat-ayat yang terkandung pada beberapa surah dan ayat yang diterangkan tentu bisa dilahat ada keterkaitan dari segi tujuan pendidikan. Dalam pendidikan pun kita mengenal ada tenaga pendidik (guru) dan murid yang dididik, ini pun sejalan kandungan ayat pada al-Qur'an tersebut di atas. Ada beberapa cara yang bisa ditempuh dalam pendidikan; 108

1. Pendidikan prasekolah informal (kelauarga)

2. Pendidikan nonformal (masyarakat)

3. Pendidikan Formal (Sekolah)

105 QS at-Tin (95): 4.

106 QS al-Fatihah (1): 2.

107 QS al-Baqarah (2): 31.

108 Lajnah Pentashihan Mushaf Al-Qur"an, Tafsir Al-Qur"an Tematik, Pendidikan, Pembangunan Karakter, dan Pengembangan Sumber Daya Manusia, (Jakarta: Badan Litbang dan Diklat Kemenag RI, 2012), h. 13. 
Pendidikan memiliki tanggungjawab sesuai dengan keterangan di atas yang mana berporos pada tiga komponen yaitu; orang tua dalam ruang lingkup keluarga, masyarakat, dan sekolah. Adapun secara umum pendidikan dan pengajaran memiliki konsep antara lain Tarbiyah, Ta "lîm dan Tazkiyah.

Aspek pertama tarbiyah; dalam kamus munawir kata tarbiyah merupakan bentuk kata rabba-yarubbu dengan makna memelihara, merawat, melindungi, dan mengembangkan, 109 menurut Syahrudin kata tarbiyah diartikannya "bertambah dan berkembang atau tumbuh dan berkembang". ${ }^{110}$ Dua pendapat ini sejalan dengan tujuan pendidikan secara umum yang mana berorientasi pada mengembangkan potensi diri atau anak didik serta dalam konteks ilmu pengetahuan menjadikan awalnya tidak tahu menjadi tahu.

Interpretasi ayat yang bisa dihubungkan dengan tarbiyah salah satunya pada surah al-Isrã ayat 24 yang berbunyi:

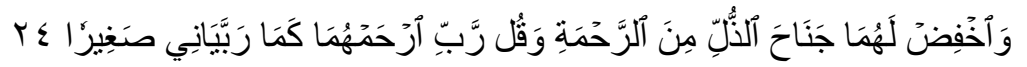

Artinya: "Dan rendahkanlah dirimu terhadap mereka berdua dengan penuh kesayangan dan ucapkanlah: "Wahai Tuhanku, kasihilah mereka keduanya, sebagaimana mereka berdua telah mendidik aku waktu kecil". 111

Sesuai dengan arti dari tarbiyah yaitu memelihara tentu berhubungan dengan konteks pendidikan seorang ibu kepada anaknya, kata "rabbayâni" yang diartikan memilihara atau mendidik pada surah al-Isrã ayat 24 di atas merupakan gambaran teladan amal kebajikan yang diimplimentasikan orang tua kepada anaknya.

Aspek kedua adalah ta"limm; kata ini pun memiliki keterkaitan dan berhubungan dengan aspek pendidikan dalam kamus Munawir merincikan kata ta"lim berasal dari kata 'allama-yu 'allimu yang berorientasi mengajar, memberi tanda, mendidik dan memberitahu. Kata ta"lîm ini dengan berbagai proses pembentukan kata yang menghasilkan kata-kata dengan paradigma yang berbeda dalam al-Qur'an terdapat 779 kali dan yang mengandung arti pengajaran diulang di dalam al-Qur'an sebanyak 42 kali. ${ }^{112}$ Bila ditinjau dari asal usul kata merupakan masdar dari kata 'allama dengan dasar kata 'alima

109 Ahmad Warson Munawwir, Kamus Al-Munawwir Arab-Indonesia Terlengkap, Cet1(Surabaya; Pustaka Progressif, 1404 H/ 1984 M), h. 462.

110 Syahidin, Menulusuri Metode Pendidikan dalam Al-Quran, (Bandung: Alfabeta, 2009), h. 38 .

111 QS al-Isrã (17): 24.

112 Muhammad Fu'àd 'Abd al-Bàqî Al-Mu'jam al-Mufahras li al-fàzh al-Qur'an al-Karîm, (Beirut: Dàr al-Fikr, 1987), h. 469-480. 
maka mempunyai arti "mengetahui". ${ }^{113}$ Dari beberapa keterangan di atas ta'lim tersebut dapat disama artikan dengan sebuah istilah pembelajaran, sedangkan di dalam pembelajaran tentu ada seorang guru atau mu'allim yang memberikaan atau bisa disebut mentranpormasikan ilmu yang dimilikinya kepada peserta didik atau disebut muta'llim.

Komponen dalam pendidikan tidak lepas dari tenaga pendidik dan peserta didik selain itu aspek pendidik dan pengajaran saling berhubungan atau bisa juga disebut $t a^{\prime} l i m$. menurut Abdel Latif dalam jurnalnya; "Ta'leem is more related to academic achievement, competence, and knowledge acquisition". ${ }^{114}$ Baginya, Ta'leem lebih berkaitan dengan prestasi akademik, kompetensi, dan akuisisi pengetahuan/ penyelesaian masalah dalam pengetahuan. Aspek ketiga adalah tazkiyah, Ahmad Warson menerangkan "kata tazkiyah terdapat dalam Alquran dengan berbagai derivasinya terulang sebanyak 69 kali". ${ }^{115}$

\section{Pendidan Keluarga}

Keluarga dalam terminology al-Qur'an menurut Muhammad Fu'àd 'Abd al-Bâqî, setidaknya terdapat dua kata yang sering digunakan yaitu "al'asyîrah" dengan berbagai derivasinya terulang sebanyak 5 kali,,116

$$
\text { ........ }
$$

Artinya: "Dan bergaullah dengan mereka secara patut".

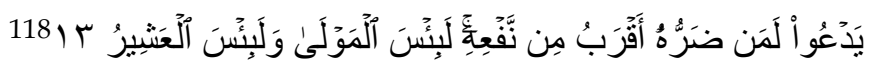

Artinya: "Ia menyeru sesuatu yang sebenarnya mudharatnya lebih dekat dari manfaatnya. Sesungguhnya yang diserunya itu adalah sejahat-jahat kawan"

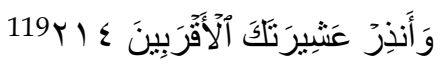

Artinya: "Dan berilah peringatan kepada kerabat-kerabatmu yang terdekat".

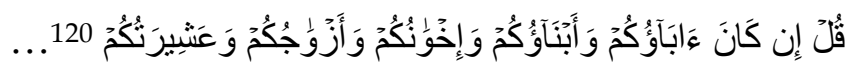

113 Muhammad Idrîs Abdul Rauf al-Marbawî, Qâmus Idrîs al-Marbawî juz I (Kairo: Musthafa Al-Babi Al-Halabi wa Awladihi, tt), h. 40.

114 Abdel Latif Sellami, Rania Sawalhi, Michael Henry Romanowski \& Tasneem Amatullah, Definitions of educational leadership Arab Educators Perspectives, International Journal of Leadership In Education, 14 November 2019, h. 13.

115 Ahmad Warson Munawwir, Kamus Al-Munawwir Arab-Indonesia..., h. 577.

116 Muhammad Fu'àd 'Abd al-Bàqî Al-Mu'jam al-Mufahras..., h. 95.

117 QS an-Nisa (4): 19.

118 QS al-Hajj (22): 13.

119 QS asy-Syu'ara, (26): 214. 
Artinya: "Katakanlah jika bapa-bapa, anak-anak, saudara-saudara, isteri-isteri, kaum keluargamu".

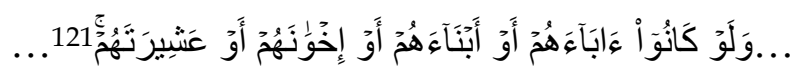

Artinya: "sekalipun orang-orang itu bapak-bapak, atau anak-anak atau saudarasaudara ataupun keluarga mereka".

Menurut Abu al 'Abbâs "kata al-ahl, diartikan sebagai kerabat, di samping juga dimaknai sebagai pengikut (al-atba') dan penghuni suatu tempat (ashâb al-makân)"122, dengan kata lain kata al-ahl tergantung konteks keseluruhannya. Misalnya al-ahl dinisbahkan dengan suatu perkara/urusan atau ahl-amr maka dapat diterjemahkan menjadi pakar (wulâtuhū), contoh yang lain apabila al-ahl dinisbatkan dengan tempat maka diartikan penghuni atau penduduknya. Yang lebih mendekati keluarga apabila kata al-ahl dikaitkan dengan nama seseorang maka tentu dimaknai adalah istri dan anak-anaknya. Ditegaskan dalam kamus al Muhîth, ada keunikan pada al-ahl yang dikaitkan dengan tempat yaitu: kata ahl al-bait yang mana tidak diartikan sebapai penghuni rumah tetapi diterjemahkan "keluarga nabi Muhammad saw dan keturunannya". ${ }^{123}$

Keterangan di atas menunjukkan dua kata yang berbeda yang biasanya ada disebut di dalam al-Qur'an namun dapat dikatakan dua kata tersebut antara al-'asyîrah dan al-ahl dapat diterjemahkan menjadi keluarga. Ditegaskan oleh Muhammad Ibn Mukarram "makna al-'asyîrah sepadan dengan kata al-ahlu yang diterjemahkan sebagai keluarga". ${ }^{124}$

Keluarga adalah pengaturan yang menyediakan pengasuhan, kasih sayang, dan berbagai kesempatan. Keluarga Islami, jika memang benar Islami, adalah ideal yang dicita-citakan orang Barat. Dengan kata lain, realitas orang Barat saat ini sangat bertolak belakang; jika mereka dapat mengatakan bahwa mereka dapat berdiri di dasar di dasar pembangunan manusia, sosial, dan etika, karena apa yang kita lihat terjadi di sekitar kita di tengah-tengah mereka, keluarga Islam dengan cita-citanya, dengan norma dan standarnya, berdiri di sebaliknya tertinggi, dan oleh karena itu, tidak ada cara yang lebih baik untuk meyakinkan pria Barat, pria atau wanita non-Muslim, tentang nilai Islam, tentang kebesaran Islam, selain mengundang mereka untuk

${ }^{120}$ QS at-Taubah (9): 24.

121 QS al-Mujâdilah (58): 22.

${ }^{122} \mathrm{Abu}$ al 'Abbâs Ahmad al Fayyūmî al-Misbâh al-Munîr fî Gharîb al-Syarh al-Kabîr, (Mawqi' al Islam), Juz 1, h. 161.

${ }^{123}$ Fairuzabadî al-Qâmūs al Muhîth, (Mawqi' al Warraq), Juz 3, h. 53.

${ }^{124}$ Muhammad Ibn Mukarram Ibn Manżhūr, Lisân al 'Arab, (Beirut: Dâr al Shâdir, t.t), Juz 4, h. 568. 
mengunjungi keluarga Muslim. Sebuah keluarga Islami dimulai dengan kedekatan antara dua keluarga dan calon pasangan. Pacaran antara suami dan istri dimulai setelah menikah dan tumbuh dan menjadi lebih kuat seiring berjalannya waktu. Dan pernikahan adalah awal bukan penyempurnaan dari proses pacaran dan cinta ini.Dalam sistem Barat, cinta dan pacaran dimulai sebelum pernikahan. Pernikahan adalah puncak dari hubungan ini, dan tidak ada kegembiraan tersisa untuk diharapkan dalam pernikahan kecuali beban tanggung jawab.

Perjodohan dalam Islam berarti pernikahan bukan dua individu, tetapi dua keluarga. Dengan demikian kedua keluarga dengan segala sumber daya manusia, ekonomi, dan kebijaksanaan mereka melayani pasangan yang baru menikah. Dan semua sumber daya ini tersedia untuk kedua pasangan jika ada masalah. Sebaliknya, pria dan wanita muda di Barat bertemu sendiri dan memutuskan untuk menikah. Dengan demikian setelah menikah mereka dibiarkan sendiri, dan tidak ada yang membantu atau membimbing mereka untuk menyelesaikan masalah perkawinan mereka. Seorang anak dalam hal ini memiliki dampak yang paling signifikan pada perkembangan anak. ${ }^{125}$ Lebih ditegaskan lagi menurut Srifariyati:

"Pendidikan keluarga adalah usaha sadar yang dilakukan orang tua, karena mereka pada umumnya merasa terpanggil (secara naluriah) untuk membimbing, mengarahkan, membekali dan mengembangkan pengetahuan nilai dan keterampilan bagi putra putri mereka sehingga mampu menghadapi tantangan hidup di masa yang akan datang". 126

Ditegaskan M. Miftah Arief, "pembiasaan yang baik akan membentuk sosok manusia yang berkepribadian baik, begitu pula sebaliknya pembiasaan yang buruk akan membentuk sosok manusia yang berkepribadian buruk". ${ }^{127}$ Model inilah yang sesungguhnya menjadi esensi utama dalam pendidikan, yang sebahagian besar proses pembentukannya terjadi dalam keluarga. Menurut Wahyu, "dalam proses pertumbuhan anak, keluarga merupakan hal terpenting yang menjadi pusat perhatian"128, hal ini disebabkan karena keluarga memberikan pengalaman pertama yang merupakan faktor yang sangat menentukan dalam pembentukan kepribadian anak.

${ }^{125}$ Roberta M. Berns, Child, Family, School, Community Socialization and Support, Edition10, (United States of America: Wadsworth Cengage Learning, 2010), h. 19.

126 Srifariyati, Pendidikan Keluarga dalam Al-Qur'an (kajian Tafsir Tematik), Madaniyah, Vol 2, Edisi XI, 2016, h. 230.

127 M. Miftah Arief, Pendidikan Pengembangan Diri Melalui Pembiasaan Optimalisasi Pendidikan Pembiasaan dan Psikologi Perkembangan, (Malang: Literasi Nusantara, 2020), h. 55.

128 Wahy u Hasbi, "Keluarga Sebagai Basis Pendidikan Pertama dan Utama", Jurnal Ilmiah Didaktika, Volume 12, Nomor 2, 2012, h. 253. 


\section{Pendidikan Keluarga Perspektif al-Qur'an}

Menurut Srifariyati, "keluarga merupakan wahana yang mampu menyediakan kebutuhan biologis anak, dan sekaligus memberikan pendidikannya sehingga menghasilkan pribadi-pribadi yang dapat hidup dalam masyarakat sambil menerima dan mengolah serta mewariskan kebudayaannya". ${ }^{129}$ Ditegaskan dalam al-Qur'an QS at-Tahrim:

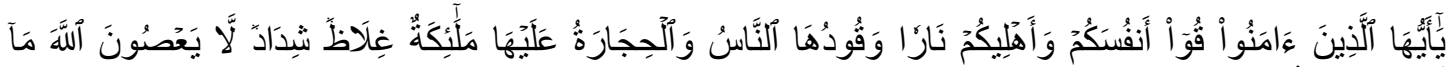

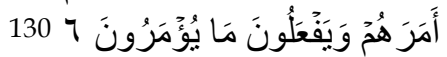

Artinya: "Hai orang-orang yang beriman, peliharalah dirimu dan keluargamu dari api neraka yang bahan bakarnya adalah manusia dan batu; penjaganya malaikat-malaikat yang kasar, keras, dan tidak mendurhakai Allah terhadap apa yang diperintahkan-Nya kepada mereka dan selalu mengerjakan apa yang diperintahkan". ${ }^{131}$

Konteks pendidikan keluarga ini memberi gambaran adanya dua orangtua yaitu ayah dan ibu dalam mendidik anaknya, dengan kata lain ayah dan ibu tidak cukup hanya menciptakan keadaan ruamah tangga yang memiliki nilai-nilai agama dan hubungan harmonis. Tetapi dalam mendidik anak juga diharuskan adanya kerjasama atau relasi dalam mendidik anaknya dilingkungan keluarganya hal ini agar tercapainya sebuah tujuan pendidikan yang diinginkan. Hal ini tergambar pada al-Qur'an Surah Thaaha:

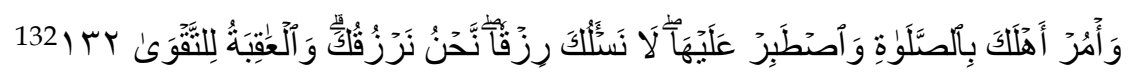

Ayat ini menunjukkan sebuah perintah antara Allah SWT kepada Nabi Muhammad SAW dan kepada setiap kepala keluarga muslim, untuk memerintahkan keluarganya mendirikan shalat secara baik danberkesinambungan, pada setiap waktunya dan bersungguh-sungguh. Dapat ditarik simpulan bahwa di dalam keluarga ada yang biasa disebut dengan kepala rumah tangga, dalam ruang lingkup keluarga biasanya dikenal dengan sosok ayah, artinya seorang ayah diwajibkan mengawasi dan menganjurkan serta mengingatkan untuk mendirikan shalat kepada istri dan anknya.

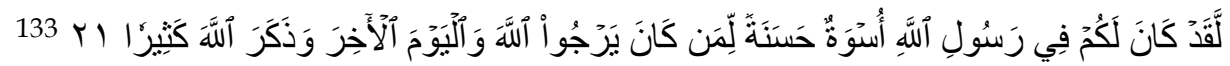

129 Srifariyati, Pendidikan Keluarga dalam Al-Qur'an..., h. 230.

130 QS at-Tahrim, (66): 6.

131 Mujamma' Khadim al Haramain al Malik Fahd, Al Qur'an dan Terjemahnya, (Madinah Munawwarah: Mujamma' Khadim al Haramainal Malik Fahd, 1412 H), h. 951.

132 QS Tāhā, (20): 132. 
Artinya: "Sesungguhnya telah ada pada (diri) Rasulullah itu suri teladan yang baik bagimu (yaitu) bagi orang yang mengharap (rahmat) Allah dan (kedatangan) hari kiamat dan dia banyak menyebut Allah".

Ayat di atas dapat disimpulkan bahwa keteladanan merupakan dari bagian pendidikan, dalam pendidikan keluarga tentu keteladanan ini merupakan salah satu pendidikan yang sangat berpengaruh bagi anak, ditegaskan Nashih 'Ulwan "keteladanan dalam pendidikan adalah cara paling efektif dan berhasil dalam mempersiapkan anak dari segi akhlak, membentuk mental, dan sosialnya",134 pernyataan tersebut menunjukkan keteladanan orangtua sangat berpengarug pada baik buruknya anak, jika orangtuanya selalu jujur serta terpercaya maka akan terpatri pada anak sifat kejujuran dan amanah.

Pendidikan keluarga memiliki tujuan antaralain mengenalkan agama Islam kepada anak sehinga menjadikan anak kuat keimananya. Pernyataan ini ditegaskan dalam al-Qur'an:

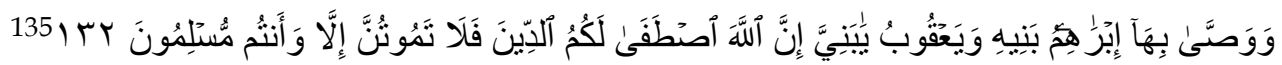

Artinya: "Dan Ibrahim telah mewasiatkan ucapan itu kepada anak-anaknya, demikian pula Yáqub. (Ibrahim berkata): "Hai anak-anakku! Sesungguhnya Allah telah memilih agama ini bagimu, maka janganlah kamu mati kecuali dalam memeluk agama Islam"

Ayat ini menggambarkan hendaknya setiap orangtua memperkenalkan anak agama Islam sebagai satu-satunya agama yang disyariatkan Allah SWT dan satu-satunya agama yang diakui, diterima, dan diridhai Allah SWT. Dalam konteks ini sebagai orangtua memiliki kewajiban mengingatkan anakanaknya walaupun sudah dewasa.

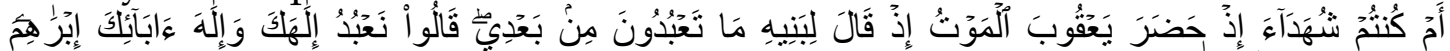

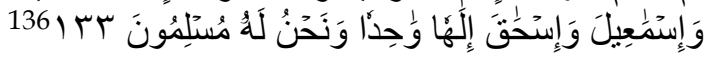

Artinya: "Adakah kamu hadir ketika Ya'qub kedatangan (tanda-tanda) maut, ketika ia berkata kepada anak-anaknya: "Apa yang kamu sembah sepeninggalku?" Mereka menjawab: "Kami akan menyembah Tuhanmu dan Tuhan nenek moyangmu, Ibrahim, Ismail dan Ishaq, (yaitu) Tuhan Yang Maha Esa dan kami hanya tunduk patuh kepada-Nya"

133 QS Al-Ahzâb, (33): 21.

134 Abdullah Nashih 'Ulwan, Tarbiyatul 'Aulâd fil Islâam, diterjemahkan oleh Arif Rahman Hakim, Cet 7 (Solo: Insan Kamil, 2014), h. 516.

135 QS Al-Baqarah, (2): 132.

136 QS Al-Baqarah, (2): 133. 


\section{Pendidikan Keluarga Perspektif Hadits}

Menurut Daradjat, "pengalaman pergaulan dalam keluarga akan memberikan pengaruh yang sangat besar bagi perkembangan anak untuk masa yang akan datang. Keluarga juga merupakan wadah pertama dan utama bagi pertumbuhan dan perkembangan anak". ${ }^{137}$ Artinya jika suasana dalam keluarga itu baik dan menyenangkan, maka anak akan tumbuh dengan baik pula, namun sebaliknya jika tidak, tentu akan terhambatlah pertumbuhan anak tersebut.

Dipertegas dalam hadits mengenai tanggung jawab kepala keluarga antara lain sebagai berikut:

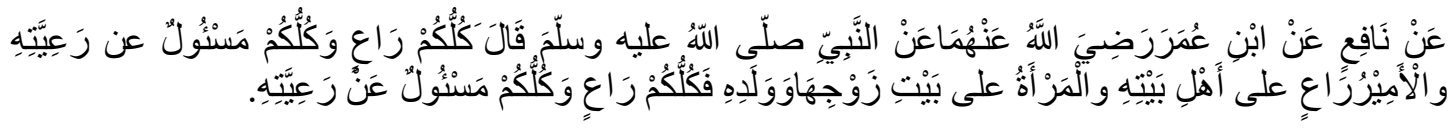

Artinya: "Setiap kalian adalah pemimpin dan setiap kalian akan dimintai pertanggungjawaban terhadap yang dipimpinnya. Seorang Amir adalah pemimpin. Seorang suami juga pemimpin atas keluarganya. Seorang wanita juga pemimpin atas rumah suaminya dan anak-anaknya, maka setiap kalian adalah pemimpin dan setiap kalian akan dimintai pertanggungjawaban atas yang dipimpinnya. (HR. Bukhari No. 4801, Muslim No. 3408, Abu Dawud No. 2539, Tirmizi No. 1627, Ahmad No. 4266)". 138

Hadis di atas mengungkapkan bahwa seorang suami atau kepala keluarga menjadi pemimpin bagi istri dan anak-anaknya. ${ }^{139}$ Dengan kata lain bahwa dalam ruang lingkup keluarga tentu sangat memerlukan bimbingan dan pendidikan dari kepala keluarga, Hadis diatas juga mengindikasikan betapa bersarnya tanggung jawab kepala keluarga (suami) dalam mendidik anggota keluarganya, baik istri maupun anak-anaknya.

Mengenai tanggung jawab yang besar dibebankan kepada kepala keluarga yang mana akan dimintai pertanggungjawaban nantinya di akhirat berkaitan dengan anggota keluarganya berkenaan dengan amal ibadahnya ditegaskan kembali pada sabda Rasulullah SAW:

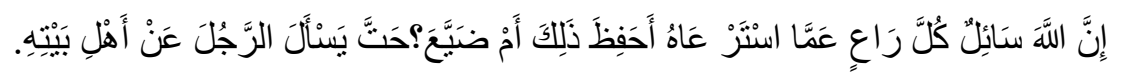

137 Zakiah Daradjat, Pendidikan Islam dalam Keluarga dan Sekolah, (Jakarta: CV. Ruhama, 2015), h. 47.

138 A. Usman Samad. Tanggung Jawab Orang Tua terhadap Pendidikan Anak dalam Perspektif Islam. Banda Aceh: Jurnal Ar-Raniry 2018.

139 Ahmad bin Ali bin Muhammad bin Muhammad bin Ali bin Mahmud bin Ahmad bin Hajar Al-Kannani Al-Asqalani Al-Mishri. Fath al-Barri fi Syarhi al-Bukhari, (Riyadh: Maktabah Darussalam, 1997), h. 391. 
Artinya: "Sesungguhnya Allah akan bertanya kepada setiap pemimpin tentang apa yang dipimpinnya. Apakah ia pelihara ataukah ia sia-siakan, hingga seseorang ditanya tentang keluarganya". ${ }^{140}$

Maka agar amal ibadah anggota keluarga diterima Allah Swt tentunya harus sesuai dengan tuntunan syariatnya, oleh karena itu suami sebagai kepala keluarga berkewajiban untuk mendidik anggota keluarganya dengan ilmu agama. Hal ini juga bersinergi dengan surah al-Tahrim ayat 6 yang dijelaskan pada poin pendidikan keluaraga perspektif al-Qur'an sebelumnya. Lebih tegas lagi menurut Syekh Saleh Al-Fauzan:

"Suami (kepala keluarga) bertanggung jawab untuk mendidiknya dan mendidik isterinya serta anak-anaknya. Siapa yang lalai dalam hal ini, kemudian sang isteri dan anak-anaknya berbuat maksiat, maka dia berdosa, karena sebabnya adalah karena dia tidak mendidik dan mengajarkan mereka". ${ }^{141}$

Selaian pengetahuan agama itu wajib diajarkan kepada anggota keluarga baik kepada istri dan anak, ada juga kewajiaban kepala keluarga mengajarkan al-Qur'an kepada istri dan anak Hadist yang mengkuatkannya persepsi ini dapat dilihat sebagai berikut:

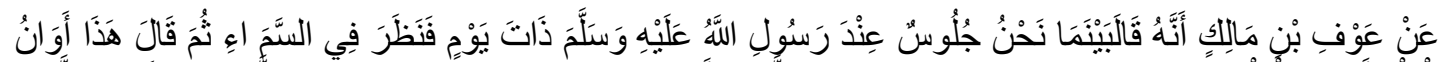

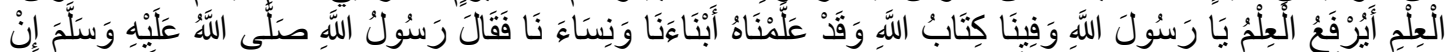

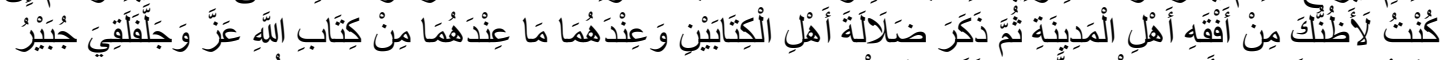

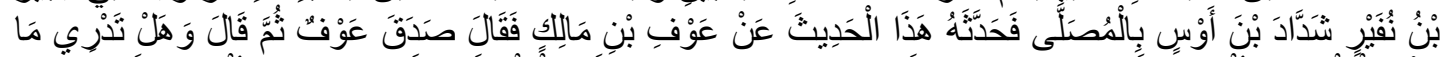

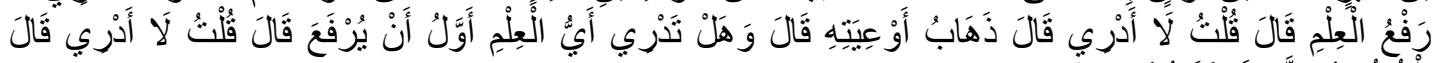

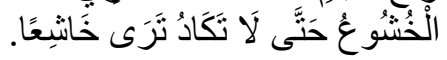

Artinya: "Apakah ilmu bisa terangkat padahal di tengah-tengah kami ada kitab Allah, kami mengajarkannya kepada anak-anak kami dan istri-istri kami?", "Rasulullah Saw menjawab: "Dulu aku mengiramu penduduk Madinah yang paling mengerti." "Setelah itu beliau menyebutkan kesesatan ahli dua kitab padahal keduanya memiliki kitab Allah 'azza wajalla yang mereka miliki. Setelah itu Jubair bin Nufair menemui Syaddad bin Aus di tempat Sholat lalu menceritakan hadits dari 'Auf bin Malik ini padanya, ia berkata: 'Auf benar. Setelah itu ia bertanya: Tahukah kamu apakah diangkatnya ilmu itu? Syaddad menjawab: Aku tidak tahu. Jubair berkata: Hilangnya wadah-wadahnya. Jubair bertanya: Tahukah kamu ilmu apa yang pertama kali terangkat? Syaddad menjawab: Aku menjawab: Aku

140 Ibnu Hajar Al-Asqalani, Fathul Baari. Kitab Al-Ahkam. Terj. Amiruddin. (Jakarta: Pustaka Aza, 2009), h. 113.

141 Syekh Saleh Al-Fauzan, Al-Muntaqa fi Fatawa Syekh Al-Fauzan, (Riyadh: Mamluk, t.th), h. 297-298. 
tidak tahu. Jubair menjawab: Kekhusyu'an hingga hampir saja kau tidak melihat orang yang khusyu". (HR. Ahmad No. 22865)". ${ }^{142}$

Hadits di atas memberikan peringatan keras kepada suami untuk mendidik istri dan anak-anaknya tentang al-Qur'an, seandainya hal ini tidak dilakukan oleh para suami, maka ilmu (al-Qur'an) akan diangkat Allah SWT dari dunia ini. Selain itu hadits tersebu mengindikasikan tanggung jawab orang tua mendidik anak-anaknya, dengan bahasa mengajarkan al-Qur'an, karena al-Qur'an sumber ilmu, agar ilmu tidak hilang dan diangkat. Lebih ditegaskan lagi oleh Abu Abdullah, "maka orang tua berkewajiban mengajarkannya kepada anak keturunannya sampai akhir hayat". ${ }^{143}$

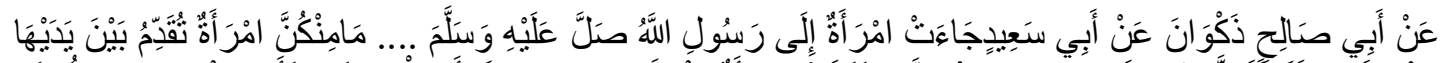

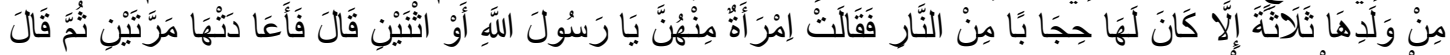

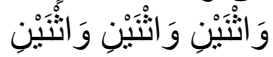

Artinya: "Dari Abu Shalih Dzakwan dari Abu Sa'id:...Tidaklah salah seorang di antara kalian melahirkan tiga anak (yang shalih), kecuali ketiga anak itu akan menjadi penghalang neraka baginya."Maka ada seorang wanita yang bertanya, 'Wahai Rasulullah, bagaimana kalau hanya dua?" Wanita itu mengulanginya hingga dua kali. Maka Rasulullah menjawab: "Sekalipun hanya dua, sekalipun hanya dua. (HR. Bukahri No. 6766; Muslim No. 4768; Ahmad No. 7053, 10869)."

Hadis di atas satu sisi memberikan pengajaran kepada kita pentingnya punya anak, pentingnya mendidik anak, sehingga jika punya anak satu, dua atau tiga dan dididik dengan baik, agar menjadi anak yang shaleh dan shalehah. Menurut Ahmad al-Misri anak yang shaleh dan shalehah akan menjadi pembela (tameng dari api neraka) bagi kedua orang taunya (dapat memberi syafaat). ${ }^{144}$ Dapat ditarik simpulan bahwa betapa pentingnya peran sosok ayah sebagai kepala keluarga dalam mendidik istri dan anak-anaknya. Siapa yang lalai dalam hal ini, kemudian sang isteri dan anak-anaknya berbuat maksiat, maka dia berdosa, karena sebabnya adalah karena dia tidak mendidik dan mengajarkan mereka.

\section{Membentuk Keluarga Bahagia dan Sejahtera}

142 Ahmad bin Muhammad bin Hanbal Asy Syaibani, Musnad Ahmad, Terj. Muhammad Iqbal, (Jakarta: Pustaka Azam, 2007), h. 875.

143 Abu Abdullah Muhammad bin Yazid Ar-Rabi' bin Majah Al-Qazwini, Sunan Ibnu Majah, Terj. Iqbal dan Mukhlis, (Jakarta: Pustaka Azam, 2005), h. 591.

144 Ahmad bin Ali bin Muhammad bin Muhammad bin Ali bin Mahmud bin Ahmad bin Hajar Al-Kannani Al-Asqalani Al-Mishri, Fathul Bari Syarah Shahih Bukhari, Terj. Amiruddin. (Jakarta: Pustaka Azam, 2009), h. 763. 
Ketika suami istri berperan besar dalam mewujudkan keluarga bahagia dan sejahtera, maka perlu menambah pengetahuan dan pemahaman tentang bagaimana membina kehidupan keluarga sesuai tuntunan agama dan tuntunan hidup bermasyarakat. Hal tersebut tentunya bertujuan agar setiap anggota keluarga, terutama suami istri, dapat menciptakan stabilitas kehidupan rumah tangga yang penuh kedamaian dan ketenangan, yang merupakan modal dasar untuk membina keluarga yang bahagia dan sejahtera.

Sejalan dengan ungkapan Abdullah Fauzi "Ketahuilah, nikah itu suatu kesunnahan (perbuatan) yang disukai dan pola hidup yang dianjurkan. Karena dengan nikah terjagalah populasi keturunan dan lestarilah hubungan antar manusia". ${ }^{145}$ Al-Qur'an, dan hukum Islam bahkan undang-undang semuanya mengatakan bahwa pernikahan adalah cara untuk menciptakan keluarga yang kekal dan bahagia. Terwujudnya perkawinan tergantung pada istri dan suami yang sama-sama memikul tanggung jawab masing-masing. Oleh karena itu, pernikahan bukan hanya kewajiban agama untuk tujuan menyenangkan Tuhan di dunia ini, tetapi juga kontrak perdata yang menimbulkan hak dan kewajiban. Beberapa cara dalam mewujudkan keluarga sejahtera diantaranya:

1. Membina keluarga yang harmonis; Dalam perkawinan, setiap orang perlu saling memahami kedudukan dan melaksanakan hak dan kewajiban masing-masing agar tercapai keharmonisan dalam rumah tangga. Salah satu kewajiban paling mendasar seorang suami terhadap istrinya adalah kewajiban menafkahi mereka baik lahir maupun batin. ${ }^{146}$ Berdasarkan kaidah-kaidah tersebut, Islam sudah sepatutnya mewajibkan seorang suami untuk menafkahi istrinya, yaitu bekerja. Istri diharapkan untuk taat kepada suaminya, mengurus rumah, dan merawat serta mendidik anakanaknya. ${ }^{147}$ Tegas dalam Al-Qur'an Surah al-Baqarah ayat 233 yang berbunyi:

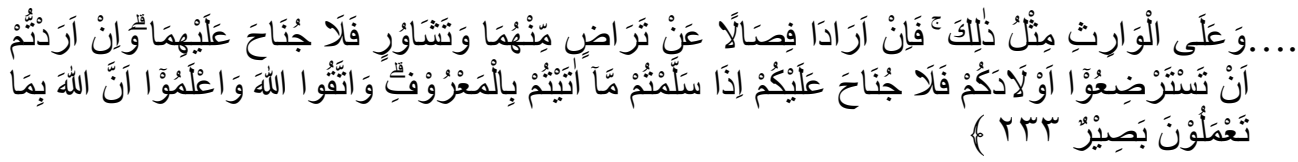

Artinya: "..Dan Kewajiban ayah menanggung makan dan pakaian mereka dengan cara yang patut. Seseorang tidak dibebani, kecuali sesuai dengan

\footnotetext{
145 Abdullah Fauzi, Fathul Izar, Bab I, (Kediri: Ats-Tsurayya, 2015), h. 2.

146 As-Subki Ali Yusuf, Fiqh Keluarga (Pedoman Berkeluarga dalam Islam), (Jakarta: Sinar Grafika Offset, 2010), h. 173.

147 Abidin Slamet dan Aminuddin, Fiqh Munakahat I, (Bandung: Pustaka Setia, 2003),h.173.
} 
kemampuannya. Janganlah seorang ibu dibuat menderita karena anaknya dan jangan pula ayahnya dibuat menderita karena anaknya. Ahli waris pun seperti itu pula. Apabila keduanya ingin menyapih (sebelum dua tahun) berdasarkan persetujuan dan musyawarah antara keduanya, tidak ada dosa atas keduanya. Apabila kamu ingin menyusukan anakmu (kepada orang lain), tidak ada dosa bagimu jika kamu memberikan pembayaran dengan cara yang patut. Bertakwalah kepada Allah dan ketahuilah bahwa sesungguhnya Allah Maha Melihat apa yang kamu kerjakan."148

2. Hubungan antara anggota keluarga dan lingkungannya yang harmonis; Keluarga bukanlah hubungan sederhana antara ayah, ibu, dan anak, tetapi mencakup hubungan yang lebih luas dengan anggota keluarga lainnya dan masyarakat. Dengan demikian menjaga dan saling membantu apabila mengalami kesusuahan setidaknya saling mendoakan jikalau tertimpa kesusahan adalah bentuk saling menjaga keharmonisan.

3. Menumbuhkan kesungguhan untuk bertanggungjawab menerima hak dan kewajiban, juga bersungguh-sungguh untuk memperoleh harta kekayaan yang halal; Menyadari tanggung jawab beristri dan mengurus segala sesuatu tentang anak akan menumbuhkan sikap rajin dan sungguhsungguh dalam memperkuat bakat dan sifat seseorang. Suami istri yang perkawinannya dilandasi oleh tuntunan agama, kerja keras dalam usahanya, dan usahanya untuk mencari kebutuhan hidup keluarganya dapat digolongkan sebagai keluarga yang beribadah. Memulai rumah tangga dapat menciptakan rasa tanggung jawab, semangat bekerja, dan berusaha mencari aset halal. ${ }^{149}$ Gizi merupakan faktor penting dalam terwujudnya kebahagiaan dan kesejahteraan keluarga. Jadi, agar bisa mewariskan keturunan yang baik dan menjaga kesehatan tubuh, pilihlah makanan yang halal dan baik. Makanan yang diperbolehkan menurut syariat Islam adalah makanan yang diperbolehkan menurut ajaran Islam untuk dimakan, yang meliputi 3 hal: makanan itu halal zat nutrisi yang terkandung, mendapatkan makanan itu diperoleh dengan cara halal, dan halal dalam cara makanan itu diolah. Dengan mengkonsumsi makanan yang halal maka akan menghasilkan sikap dan akhlak yang mulia bagi anak-anak kita.

4. Membangun rumah tangga untuk membentuk masyarakat yang tentram atas dasar cinta dan kasih sayang; Keluarga merupakan struktur kecil dalam suatu bangsa yang memiliki kontribusi besar bagi bangsa. Oleh karena itu, jika suatu masyarakat terdiri dari keluarga-keluarga yang kuat, maka akan kuat pula suatu masyarakat, begitu pula sebaliknya.

148 QS Al-Baqarah, (2): 233.

149 Abdul Rahman Ghozali, Figh Munakahat, Cetakan Ketiga, (Jakarta: Kencana, 2008),h.30. 
Pernikahan mengajarkan manusia untuk bertanggung jawab atas segala akibat yang timbul karenanya. Dari rasa tanggung jawab, dan rasa cinta terhadap keluarga, muncul keinginan untuk mengubah masa depannya menjadi lebih baik dengan berbagai cara. ${ }^{150}$ Sejalan dengan firman Allah SWT surah Ar-Rum ayat 21 yang berbunyi:

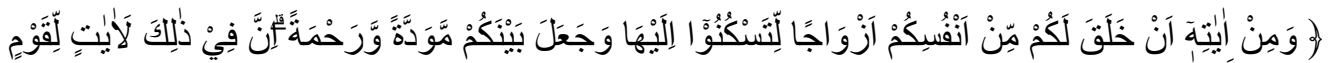

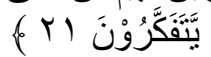

Artinya: "Di antara tanda-tanda (kebesaran)-Nya ialah bahwa Dia menciptakan pasangan-pasangan untukmu dari (jenis) dirimu sendiri agar kamu merasa tenteram kepadanya. Dia menjadikan di antaramu rasa cinta dan kasih sayang. Sesungguhnya pada yang demikian itu benar-benar terdapat tanda-tanda (kebesaran Allah) bagi kaum yang berpikir."151

Berdasarkan ayat di atas, rumah tangga dalam Islam terbentuk dalam keterpaduan antara ketentraman (sakinah), penuh rasa cinta (mawaddah), dan kasih sayang (rahmah). Dengan demikian kunci untuk menjadikan keluarga bahagia dan sejahtra adalah keharmonisan. Salah satu perhatian Islam (yang merupakan sesuatu yang ingin diciptakan oleh para pengikut agama) adalah penciptaan aturan dan hukum yang adil, fleksibel, dan bijaksana. Jika orang mengikuti aturan dengan setia dan jujur, tidak akan ada konflik. Hidup akan tentram dan damai. Kedamaian dalam puisi ini juga dapat dinikmati oleh anggota masyarakat.

\section{Kesimpulan}

Pendidikan merupakan usaha sadar yang dilakukan seseorang atau berkelompok untuk mendewasakan anak, mentransformasi pengetahuan, ketrampilan, dan nilai-nilai sikap agar kehidupannya berubah menjadi lebih baik dari sebelumnya Kehadiran keluarga dalam diskursus pendidikan, merupakan suatu keniscayaan yang tidak dapat dihindari, hal ini berangkat dari adanya kesadaran mendasar, bahwa keluarga merupakan kelompok sosial pertama bagi manusia. Dalam keluargalah untuk pertama kalinya, manusia belajar berkomunikasi dan berinteraksi dengan manusia lainnya, dalam keluarga pula manusia berupaya mengenal dirinya, dan kemudian berusaha mengkonstruksi kehidupannya. Al-Qur'an menegaskan bahwa Allah SWT telah memerintahkan kepada orang-orang yang beriman agar memelihara dirinya dan keluargnya yang terdiri dari istri, anak, saudara, kerabat, hamba sahaya untuk taat kepada Allah. Dan agar ia melarang

150 Beni Ahmad Saebani, Fiqh Munakahat, Cetakan Pertama, (Bandung: Pustaka Setia, 2001), h. 45.

151 QS Ar-Rum, (2): 233. 
dirinya beserta semua orang yang berada dibawah tanggung jawabnya untuk tidak melakukan kemaksiatan kepada Allah.

\section{Referensi}

'Abd al-Bàqî, Muhammad Fu'àd. Al-Mu'jam al-Mufahras li al-fàzh al-Qur'àn alKarîm. Beirut: Dàr al-Fikr. 1987.

Abdullah, Abu, Muhammad bin Yazid Ar-Rabi' bin Majah Al-Qazwini. Sunan Ibnu Majah, Terj. Iqbal dan Mukhlis. Jakarta: Pustaka Azam. 2005.

Abdullah, M. Imron. Pendidikan Keluarga Bagi Anak. Cirebon: Lektur. 2003.

Ahmad, bin Ali bin Muhammad bin Muhammad bin Ali bin Mahmud bin Ahmad bin Hajar Al-Kannani Al-Asqalani Al-Mishri. Fath al-Barri fi Syarhi al-Bukhari. (Riyadh: Maktabah Darussalam, 1997.

Ahmad, bin Ali bin Muhammad bin Muhammad bin Ali bin Mahmud bin Ahmad bin Hajar Al-Kannani Al-Asqalani Al-Mishri. Fathul Bari Syarah Shahih Bukhari, Terj. Amiruddin. Jakarta: Pustaka Azam. 2009.

Ahmadi, Abu. Sosiologi Pendidikan. Jakarta: Rineka Cipta. 2007.

Al 'Arabiyyah, Majma' al-Lughah. al Mu'jam al-Wasît. Kairo: Maktabah Syuruq al Dauliyyah. 2004.

Al Fayyūmî, Abu al 'Abbâs Ahmad. al-Misbâh al-Munîr fî Gharîb al-Syarh alKabîr. Mawqi' al Islam. Juz 1.

Al-Fauzan, Syekh Saleh. Al-Muntaqa fi Fatawa Syekh Al-Fauzan. Riyadh: Mamluk. t.t.

Aminur, Nuruddin. dan Akmal, Tarigan Azhari. Hukum Perdata Islam di Indonesia. Jakarta: Kencana, 2004.

Anis, Ibrahim. dkk, Al-Mu'jam Al-Wasit, Mesir: Majma' Al-Lughah AlArabiyyah. 1972.

Arief, M. Miftah. Pendidikan Pengembangan Diri Melalui Pembiasaan Optimalisasi Pendidikan Pembiasaan dan Psikologi Perkembangan. Malang: Literasi Nusantara. 2020.

Berns, Robert M. Child, Family, School, Community Socilization and Support. United State: Thomson Corporation. 2007.

Berns, Roberta M. Child, Family, School, Community Socialization And Support. Edition-10. United States of America: Wadsworth Cengage Learning. 2010.

Daradjat, Zakiah. Pendidikan Islam dalam Keluarga dan Sekolah.Jakarta: CV. Ruhama. 2015.

Dinas Pendidikan dan Kebudayaan, Kamus Besar Bahasa Indonesia. Jakarta: Balai Pustaka. 2003.

Fairuzabadî. al-Qâmūs al Muhîth. Mawqi' al Warraq. Juz 3.

Fauzi, Abdullah Fathul Izar. Bab I. Kediri: Ats-Tsurayya. 2015. 
Ghozali, Abdul Rahman. Figh Munakahat. Cetakan Ketiga. Jakarta: Kencana. 2008.

Hajar, Ibnu, Al-Asqalani. 2009. Fathul Baari. Kitab Al-Ahkam. Terj. Amiruddin. Jakarta: Pustaka Azam.

Hajar, Ibnu, Al-Asqalani. Fathul Baari. Kitab Al-Ahkam. Terj. Amiruddin. Jakarta: Pustaka Azam. 2009.

Halim, Nipan Abdul. Anak saleh Dambaan Keluarga. Yogyakarta: Mitra Pustaka, 2003.

Ibn Manżhūr, Muhammad Ibn Mukarra. Lisân al 'Arab. Beirut: Dâr al Shâdir. t.t. Juz 4

Ibn Mufdlal, Muhammad Husein. Ar-Râghib al Asfihânî al Mufradât fî Gharî̉ Alqurãn. Damaskus: Dâr al Qalâm, t.t. juz 2.

Jawas, Yazid bin Abdul Qadir. Panduan Keluarga Sakinah. Jakarta: Pustaka Imam Syafi'i. 2011.

Lajnah Pentashihan Mushaf Al-Qur"an. Tafsir Al-Qur"an Tematik, Pendidikan, Pembangunan Karakter, dan Pengembangan Sumber Daya Manusia. Jakarta: Badan Litbang dan Diklat Kemenag RI. 2012.

Munawwir, Ahmad Warson. Kamus Al-Munawwir Arab-Indonesia Terlengkap. Cet-1 Surabaya; Pustaka Progressif. 1404 H/ 1984 M.

'Ulwan, Abdullah Nashih. Tarbiyatul 'Aulâd fil Islâam. diterjemahkan oleh Arif Rahman Hakim. Cet 7 Solo: Insan Kamil. 2014.

Reza Zakaria, News liputan6, 25 Agu 2020, 18:00 WIB, https:// www.liputan6.com/regional/read/4339396/video-bocah-6tahun-babak-belur-dan-patah-tulang-disiksa-ibu-kandung-dankekasihnya, diakses pada Rabu, 23 September 2020, Pukul15.22 Wita.

Saebani, Beni Ahmad. Figh Munakahat. Cetakan I. Bandung: Pustaka Setia. 2001.

Samad, A. Usman. Tanggung Jawab Orang Tua terhadap Pendidikan Anak dalam Perspektif Islam. Banda Aceh: Jurnal Ar-Raniry 2018.

Slamet, Abidin. dan Aminuddin. Figh Munakahat I. Bandung: Pustaka Setia, 2003.

Srifariyati. Pendidikan Keluarga dalam Al-Qur'an (kajian Tafsir Tematik). Madaniyah. Vol 2. Edisi XI. 2016.

Syahidin. Menulusuri Metode Pendidikan dalam Al-Quran. Bandung: Alfabeta. 2009.

Undang-Undang Republik Indonesia Nomor 20 Tahun 2003 Tentang Sistem Pendidikan Nasional.

Yohana Neni, "Konsep Pendidikan Dalam Keluarga", OASIS, Volume 2, Nomor 1, Tahun 2017.

Yusuf, As-Subki Ali, Figh Keluarga (Pedoman Berkeluarga dalam Islam). Jakarta: Sinar Grafika Offset. 2010. 